\author{
Katarzyna Jędraszczyk \\ (Poznań-Gniezno) \\ https://orcid.org/0000-0003-0658-0985 \\ Igor Krywoszeja \\ (Humań) \\ https://orcid.org/0000-0003-1429-8293
}

\title{
OD WSPÓŁPRACY MIAST \\ DO WSPÓŁPRACY AKADEMICKIEJ - PRZYKŁAD PAŃSTWOWEGO UNIWERSYTETU IM. PAWŁA TYCZYNY W HUMANIU I UNIWERSYTETU IM. ADAMA MICKIEWICZA W POZNANIU (INSTYTUTU KULTURY EUROPEJSKIEJ UAM)
}

\begin{abstract}
The article describes various aspects of academic cooperation between two universities: the Pavlo Tychyna Uman State Pedagogical University (Ukraine) and the Adam Mickiewicz University in Poznan (Poland), especially the AMU Institute of European Culture in Gniezno (formerly the European College, Adam Mickiewicz University). The description of the scientific, cultural and teaching activities of both centers suggests a model of cooperation built on the basis of regular grassroots activity.
\end{abstract}

\section{Key words}

academic cooperation, Poland-Ukraine, Uman, Gniezno, Poznań, Adam Mickiewicz University

Ukraina i Polska to nie tylko sąsiedzi, ale także partnerzy, których współpraca obejmuje również wymianę naukową i transfer wiedzy. W jej ramach przygotowywane są wspólne projekty, działania kulturalne i oświatowe. Wiele miast i uczelni rozpoczęło w latach dziewięćdziesiątych i dwutysięcznych współpracę kulturalną 
i akademicką, w praktyce realizując nieprecyzyjną ideę strategicznego partnerstwa ukraińsko-polskiego, postulowaną przez polityków ${ }^{1}$. Relacje uczelniane i samorządowe budowano w znacznej mierze spontanicznie, licząc, że uda się je oprzeć na kontaktach oddolnych. Praktyka pokazała, że nie zawsze były one jednak, zwłaszcza na szczeblu samorządowym, wystarczająco efektywne, głównie z powodu podatności na zmiany personalne i polityczne. Istnieją jednak przykłady budowanej oddolnie współpracy trwałej, zwłaszcza akademickiej. Jeden z nich jest przedmiotem niniejszej analizy.

Tekst ma w dużej mierze charakter faktograficzny, a jego celem jest diagnoza aktywności, refleksja nad możliwościami dalszej współpracy oraz zwiększania/ utrzymania jej efektywności. Przedmiotem namysłu w analizie chronologiczno-problemowej jest współpraca Uniwersytetu Pedagogicznego im. Pawła Tyczyny w Humaniu (dalej UDPU²) na Ukrainie i Uniwersytetu im Adama Mickiewicza w Poznaniu (dalej UAM), a zwłaszcza Instytutu Kultury Europejskiej Uniwersytetu im. Adama Mickiewicza (filia w Gnieźnie, dalej IKE UAM) ${ }^{3}$. Opis współpracy na linii uniwersytet jako całość (po stronie ukraińskiej) i instytut/filia (po stronie polskiej) - nie jest przypadkowy. Ta asymetria związana jest $\mathrm{z}$ realnie największą na UAM współpracą tej jednostki (ośrodka zamiejscowego w strukturze UAM do 2009, potem jednostki podstawowej UAM, a od października 2019 r. filii) z uniwersytetem w Humaniu.

Współpraca w dziedzinie edukacji i nauki między Ukrainą a Rzeczpospolitą Polską odbywa się w oparciu o Umowę między Rządem Rzeczypospolitej Polskiej a Rządem Ukrainy o współpracy w dziedzinie kultury, nauki i oświaty, zawartą 20 maja 1997 r. $^{4}$ oraz Porozumienie o współpracy między Ministrem Edukacji Narodowej Rzeczypospolitej Polskiej a Ministerstwem Oświaty i Nauki Ukrainy, sporządzone w Górowie Iławeckim 2 lipca 2001 r. ${ }^{5}$ Zgodnie z tymi umowami strony zobowiązują się sprzyjać wymianom studenckim, doktoranckim, wymianom pracowników naukowych i bezpośredniej współpracy między uczelniami. Oczywiście ważne jest, aby coraz więcej ukraińskich uczelni uczestniczyło we współpracy bilateralnej z polskimi uczelniami. Najbardziej pożądanymi cechami współpracy międzyuczelnianej są ciągłość, trwałość oraz partnerski charakter.

\footnotetext{
1 Jędraszczyk 2010, s. 84-109.

2 Akronim od Umansky Derżawny Pedagogiczny Uniwersytet.

${ }^{3}$ Instytut Kultury Europejskiej do 2009 r. funkcjonował pod nazwą Kolegium Europejskie. Po 2009 r. Instytut Kultury Europejskiej UAM, potem jednostka podstawowa UAM (instytut na prawach wydziału), a po zmianach strukturalnych na UAM związanych z tzw. Konstytucją dla Nauki IKE jest filią UAM. Szerzej: Poznaj nasz Instytut 2021.

${ }^{4}$ Dz.U. 2000, nr 3, poz. 29.

${ }^{5}$ M.P. 2002, nr 6, poz. 127.
} 
Kwestia polsko-ukraińskiej współpracy naukowo-dydaktycznej pozostaje zagadnieniem mało zbadanym. Głównie są nim zainteresowani badacze polsko-ukraińskiej współpracy kulturalnej. W tym kontekście istotne znaczenie ma praca badawcza Żanny Tocenko pt. „Współpraca w dziedzinie kultury jako składnik ukraińsko-polskich stosunków humanitarnych"6. Współpraca pomiędzy UDPU w Humaniu a polskimi instytucjami naukowo-edukacyjnymi została opisana w artykułach naukowych autorstwa Ihora Krywoszeji ${ }^{7}$ i Oksany Zabołotnej ${ }^{8}$. Doświadczenia UDPU w realizacji dwóch programów mobilności akademickiej („Trzy dyplomy - klucz do mobilności zawodowej” oraz Interdyscyplinarnych Indywidualnych Studiów Humanistycznych) przedstawiono natomiast w artykule Julii Muzyczenko9. Informacje o programach międzynarodowych i udziale w nich studentów oraz nauczycieli uczelni opisano na łamach czasopisma UDPU „Wiadomości Pedagogiczne"10. O polsko-ukraińskiej wymianie młodzieży oraz programach i projektach, w których uczestniczyło miasto Humań i UDPU, pisał też

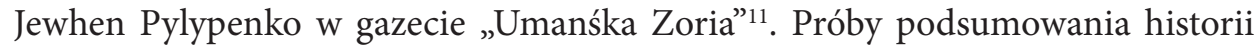
współpracy UDPU w Humaniu z placówkami naukowo-dydaktycznymi RP podjęła się także Olena Dżagunowa ${ }^{12}$. Pewne informacje o partnerstwie i wspólnych projektach zawarte są w artykułach wyżej wymienionych naukowców, dotyczących partnerskich kontaktów między miastem Humań a polskimi miastami ${ }^{13}$.

Od kilku lat temat ten nie był podejmowany, choć współpraca jest kontynuowana. Konieczne jest zatem uzupełnianie faktografii, analizy i diagnozy działań w zakresie współpracy podjętych po 2012 roku.

Źródłowe podstawy tematu można podzielić na następujące grupy: umowy o współpracy i współpracy międzynarodowej, sprawozdania rektorów UDPU, raporty z działalności międzynarodowej i naukowej, publikacje w prasie ukraińskiej i zagranicznej, opublikowane zbiory materiałów z konferencji sprawozdawczo-naukowych, naukowo-metodycznych i naukowo-praktycznych, zasoby elektroniczne, notatki i sprawozdania koordynatorów współpracy ${ }^{14}$, i inne.

6 Tocenko 2012.

7 Krivošeâ 2011, s. 92-95, idem 2012, s. 387-398.

8 Krywoszeja, Zabolotna 2009, s. 267-270; iidem 2011, s. 161-165; iidem 2012, s. 348-354; Krivošeâ 2012, s. 387-398; Krivošeâ, Zabolotna 2013, s. 515-521.

9 Muzičenko 2009, s. 83-89.

10 Brit, Zabolotna 2011.

11 Pilipenko 2009.

12 Džagunova 2017, s. 165-179.

13 Krivošeâ, Zabolotna 2010, s. 178-187.

14 Koordynatorzy dr Katarzyna Jędraszczyk i prof. Ihor Krywoszeja, będący jednocześnie autorami tej publikacji, dysponują materiałami powstałymi w toku wieloletniej współpracy, stanowiącymi bazę niniejszego opracowania. 


\section{GNIEZNO I HUMAŃ JAKO MIASTA PARTNERSKIE}

U podstaw rozwoju współpracy między Humaniem a polskimi miastami leży przeszłość historyczna oraz podobny profil społeczno-ekonomiczny miast, czego konsekwencją było podpisanie umów partnerskich między miastami i placówkami oświatowymi. Zanim skupimy się na współpracy akademickiej, warto podkreślić, że była ona początkowo ściśle powiązana ze współpracą miast, a u jej podstaw legła idea partnerstwa Gniezna i Humania ${ }^{15}$. Około 2005 roku władze Gniezna skierowały do Ambasady Ukrainy w Polsce zapytanie o możliwość znalezienia miasta, które chciałoby rozpocząć współpracę z Gnieznem. Wytypowano Humań jako miasto o podobnej strukturze społeczno-ekonomicznej i znaczeniu historycznym. Miasta rozpoczęły współpracę w maju $2005 \mathrm{roku}^{16}$. Z czasem, niejako naturalnie, w działania miasta włączyło się także Kolegium Europejskie w Gnieźnie, będące wówczas ośrodkiem zamiejscowym Uniwersytetu im. Adama Mickiewicza, a ze strony Humania - Państwowy Uniwersytet Pedagogiczny im. Pawła Tyczyny. Pracownicy obu środowisk uniwersyteckich mieli okazję poznać się podczas spotkań organizowanych przez samorząd Gniezna, co doprowadziło do podpisania umowy o współpracy pomiędzy uniwersytetami 3 października 2005 r. Z umową był powiązany aneks o ścisłej współpracy Kolegium Europejskiego UAM i Instytutu Oświaty Społecznej i Artystycznej UDPU ${ }^{17}$. Rektor Państwowego Uniwersytetu Pedagogicznego w Humaniu oraz dyrektor Kolegium Europejskiego UAM podpisali też 21 listopada 2007 r. umowę o utworzeniu i wspieraniu Polskiego Centrum Kulturalno-Oświatowego przy uniwersytecie w Humaniu. W aspekcie akademickim umowa realizowała się poprzez wspólne projekty dydaktyczne, publikacyjne i udział w konferencjach naukowych.

W 2006 roku studenci i wykładowcy UDPU wzięli udział w letniej szkole nauki języka polskiego (Polonikum, wrzesień 2006, Gniezno), międzynarodowej szkole letniej „Uniwersytety w rozwoju demokracji w Europie” (wrzesień 2006, Gniezno-Zamek Czocha-Kraków), w której wzięli udział przedstawiciele Bułgarii, Polski i Ukrainy. W październiku tego samego roku profesorowie obu uczelni uczestniczyli w odbywającym się w Gnieźnie Międzynarodowym Kolokwium „Drogi i skrzyżowania dialogu międzykulturowego”. UDPU było partnerem Gniezna i Kolegium Europejskiego UAM w realizacji międzynarodowego projektu „Gniezno-Humań: polsko-ukraiński personel dla Europy”, w ramach szeroko za-

${ }^{15}$ Gniezno ma 10 miast partnerskich, w tym jedno z Ukrainy - Humań. Humań ma 15 miast partnerskich, w tym 5 miast polskich (Łańcut, Gniezno, Częstochowa, Kórnik, Szprotawa). Szerzej: Miżnarodni zwjazky 2021.

${ }^{16}$ Umowę podpisali: ze strony Gniezna - prezydent miasta Jaromir Dziel, ze strony Humania mer Jurij Bodrowyj.

17 Treść umowy i aneksu dostępna w intranecie pracowników UAM. 
krojonego programu „Polska Pomoc”, finansowanego przez Ministerstwo Spraw Zagranicznych i realizowanego od września do grudnia $2007 \mathrm{r}^{18}$

Jednym z pierwszych dużych spotkań naukowych była konferencja „Polska-Ukraina: o przeszłości dla przyszłości”, która odbyła się w maju 2008 r. W grudniu 2008 r. pod patronatem mera miasta Humań, burmistrza Łańcuta i prezydenta Gniezna odbyła się międzynarodowa interdyscyplinarna konferencja naukowa „Polska - Europa - Ukraina - przeszłość, teraźniejszość, przyszłość”. Wspomnieć trzeba też o akcji społecznej z 2009 roku. Prezydent Miasta Gniezna Jacek Kowalski i Przewodniczący Rady Miejskiej Jerzy Stachowiak przekazali 16 października 2009 r. ok. 2000 książek zebranych przez mieszkańców Gniezna na rzecz Polskiego Centrum Kulturalno-Oświatowego w Humaniu ${ }^{19}$. Był to ważny gest, który powiązał współpracę mieszkańców miast z działaniami naukowymi i dydaktycznymi.

Od 2009 roku Polskie Centrum Kulturalno-Oświatowe w Humaniu rozszerzyło swoją działalność poza uniwersytet, kierując ofertę edukacyjno-kulturalną do wszystkich mieszkańców Humania. Przykładem takich działań był polsko-ukraiński program wymiany młodzieży. Po raz pierwszy w kwietniu-maju 2009 r. dzięki dofinansowaniu Narodowego Centrum Kultury w takim projekcie wzięło udział 28 uczniów i studentów z Humania oraz uczniowie Szkoły Podstawowej nr 3 im. św. Wojciecha w Gnieźnie. Koordynatorami projektu był dyrektor tej szkoły Radosław Sobkowiak i wykładowca UDPU prof. Oksana Zabołotna ${ }^{20}$. Humań reprezentowali studenci Państwowego Uniwersytetu Pedagogicznego im. Pawła Tyczyny i Państwowej Akademii Rolniczej w Humaniu, a także uczniowie Gimnazjum Miejskiego oraz IV Liceum Ogólnokształcącego. Do 2020 roku w cyklicznie odbywających się projektach uczestniczyło ponad 200 osób, w tym około stu młodych ludzi z Humania. W ramach tych wymian studenci Państwowego Uniwersytetu Pedagogicznego im. Pawła Tyczyny, uczący się języka polskiego, mieli okazję do odbycia praktyki językowej, zwiedzenia kraju i zdobcia umiejętności prowadzenia badań $\mathrm{w}$ wielokulturowym środowisku ${ }^{21}$. Jak wynika $\mathrm{z}$ ankiety ewaluacyjnej przeprowadzonej wśród uczestników projektu, dzięki temu doświadczeniu uzyskali oni możliwość rozwoju zawodowego, większy wpływ na proces edukacyjny, a także zrozumieli, czym jest rzetelność pracy akademickiej. Współpraca nie zakończyła się wraz z finałem projektu. Co roku od kilku lat odbywa się także konkurs języka angielskiego, w którym uczestniczą uczniowie z Humania i Gniezna. Uczniowie o tej samej porze piszą test i wyłaniają indywidualnych i grupowych zwycięzców. Regularnie odbywa się wymiana uczniowska i kształcenie kadr nauczycielskich.

\footnotetext{
18 Zvìt z mižnarodnoï diâl'nostì 2007.

19 Pilipenko 2009.

20 Ibidem.

21 Kirej 2016.
} 
W listopadzie 2013 r. w miastach partnerskich Humania i uczelniach partnerskich UDPU otwarto wystawę kopii dokumentów „Echa powstania styczniowego w Humaniu" poświęconą 150. rocznicy powstania 1863-1864. Wystawę zorganizowały Wydział Historyczny UDPU, Polskie Centrum Ośrodek Kulturalno-Oświatowy, Państwowy Rezerwat Historyczno-Architektoniczny „Stary Humań”, Centralne Państwowe Archiwum Historyczne Ukrainy w Kijowie, Państwowe Archiwum Okręgu Kijowskiego przy wsparciu Ambasady RP na Ukrainie. Wystawa była prezentowana w Warszawie, Gnieźnie, Krakowie, Kórniku, Łańcucie i Częstochowie ${ }^{22}$.

\section{POLSKIE CENTRUM KULTURALNO-OŚWIATOWE W HUMANIU A WSPÓŁPRACA UCZELNIANA}

Polskie Centrum Kulturalno-Oświatowe w Humaniu powstało na mocy porozumienia pomiędzy Państwowym Uniwersytetem Pedagogicznym im. Pawła Tyczyny a Uniwersytetem im. Adama Mickiewicza 21 listopada 2007 r. Celem tej umowy było zacieśnienie więzi między tymi uczelniami, wsparcie dla badań z zakresu historii, kulturoznawstwa, pedagogiki, filologii, literaturoznawstwa w Polsce i na Ukrainie; organizacja praktyk studenckich ${ }^{23}$.

Uroczyste otwarcie centrum odbyło się 28 maja 2008 r. z udziałem Rektora UDPU prof. Mychajło Martyniuka oraz dyrektora Kolegium Europejskiego im. Jana Pawła II prof. Aleksandra Mikołajczaka. W uroczystości otwarcia uczestniczyli Konsul Generalny RP w Kijowie Grzegorz Opaliński, Prezydent Miasta Gniezna Jacek Kowalski, Przewodniczący Rady Miasta Gniezna Jerzy Stachowiak, a także Prezes Towarzystwa Przyjaźni Pomorza z Zagranicznymi Miastami Partnerskimi oraz Prezes Towarzystwa Polaków w Humaniu, wykładowcy i studenci uniwersytetu, przedstawiciele mediów ${ }^{24}$.

Równolegle $\mathrm{z}$ otwarciem centrum odbyła się międzynarodowa konferencja „Polska - Ukraina: o przeszłości dla przyszłości (w 240. rocznicy powstania 17681769 na prawobrzeżnej Ukrainie)", w której udział wzięli naukowcy z ukraińskich uczelni oraz naukowcy z Poznania, Łańcuta i Częstochowy.

Ośrodek powstał i działa do dziś z myślą o szerokim zaangażowaniu wykładowców, lekarzy, doktorantów, studentów, nauczycieli w wymianę kadr i doświadczeń oraz edukowaniu w zakresie języka, historii, kultury polskiej. Koordynuje prace instytutów/wydziałów w zakresie polsko-ukraińskich badań naukowych, współ-

22 Nasz Uniwersytet 2013.

${ }^{23}$ Ugoda pro stvorennâ Pol's'kogo kul'turno-osvìtn’ogo znajduje się w zasobach archiwum IKE UAM i Polskiego Centrum Kulturalno-Oświatowego w Humaniu.

${ }^{24}$ Krivošeâ, Zabolotna 2010, s. 183. 
pracy edukacyjnej i kulturalnej ${ }^{25}$. Z punktu widzenia IKE UAM najistotniejsza jest koordynacja rekrutacji studentów chcących uczestniczyć w programie „studiów paralelnych" oraz ich przygotowanie językowe do studiów w Polsce.

Centrum współpracuje od 2008 r. z Towarzystwem Polaków „Ognisko” w Humaniu oraz pozostałymi polskimi miastami partnerskimi Humania. Naukowcy związani z miastami i uczelniami w Częstochowie, Poznaniu i Gnieźnie wielokrotnie prowadzili wykłady w Polskim Centrum ${ }^{26}$.

Na Państwowym Uniwersytecie Pedagogicznym im. Pawła Tyczyny 1 września 2009 r. dzięki wsparciu z UAM i Kolegium Europejskiego uruchomiono Interdyscyplinarne Indywidualne Studia Humanistyczne (MIGUS). Program MIGUS był próbą odejścia od tradycyjnej formy edukacji na rzecz interdyscyplinarności w naukach humanistycznych. Studenci, którzy kończyli te studia, oprócz dyplomu uczelni ukraińskiej, otrzymywali zaświadczenie o wszystkich dodatkowych kursach w ramach programu. Uman Collegium MIGUS był nadzorowany merytorycznie przez Uniwersytet im. Adama Mickiewicza, którego profesorowie brali udział także w pracach komisji egzaminacyjnych. Projekt Interdyscyplinarnych Indywidualnych Studiów Humanistycznych w Polsce (MISH) i na Ukrainie był związany z Wydziałem Interdyscyplinarnych Studiów „Artes Liberales” Uniwersytetu Warszawskiego. Oprócz przedmiotów na własnym wydziale, studenci mieli możliwość studiowania na kierunkach oferowanych na wydziale historycznym, kierunkach filologii ukraińskiej i obcej. Kształcenie trwało trzy lata.

Od początku swojej działalności Centrum zainicjowało szereg konferencji i wydarzeń kulturalno-edukacyjnych, mających na celu rozszerzenie polsko-ukraińskiej współpracy naukowej i edukacyjnej.

\section{WSPÓŁPRACA AKADEMICKA}

Pracownicy naukowi w Humaniu prowadzą badania dotyczące muzealnictwa, historii Polski oraz systemu szkolnictwa w Polsce. Obie strony korzystały z możliwości rozwoju naukowego, jakie dawały wyjazdy do uniwersytetu partnerskiego, pracownicy odbywali kwerendy, prowadzili wykłady, organizowali wspólne wykłady, zapraszali się nawzajem do publikowania w czasopismach i monografiach zbiorowych. Naukowcy z Humania prowadzą także badania z zakresu kultury żydowskiej na tym obszarze, znaczenia grekokatolicyzmu na Ukrainie (Klasztor Bazylianów w Humaniu) i historii społecznej Humania. Tymi aspektami za-

${ }^{25}$ Ugoda pro stvorennâ Pol's'kogo kul'turno-osvitn'ogo.

${ }^{26}$ Tadeusz Epstein, Katarzyna Jędraszczyk, Rafał Dymczyk, Tadeusz Srogosz, Norbert Morawiec $\mathrm{i}$ inni. 
interesowane jest także środowisko naukowe IKE UAM. Pracownicy IKE UAM dostrzegają możliwości przyszłej współpracy w zakresie badań nad krajobrazem (Park Sofijówka) oraz badań z zakresu nowych mediów i metod dydaktycznych. Składając dokumentację na wyjazdy w ramach Erasmus Plus, podkreślano także znaczenie faktu, że pracownicy IKE UAM są przygotowani do przeprowadzenia zajęć dydaktycznych związanych z tematyką nowych mediów, historii najnowszej Polski, stosunków polsko-ukraińskich, co szczególnie pomocne będzie dla studentów i kadry planującej studia lub staże w IKE UAM. W wyniku naboru na Erasmus Plus w 2019/2020 rok Uniwersytet Pedagogiczny w Humaniu mógł wysłać na wymianę jednego naukowca.

Współpracę UAM i UDPU można podzielić z perspektywy uczelni ukraińskiej i polskiej. Tu jednak spróbujemy nadać im wspólną chronologię:

2005-2009 - rozpoczęcie współpracy, instytucjonalizacja

Rektorem UDPU był prof. Mychajło Martyniuk, rektorem UAM prof. Stanisław Lorenc, a od 2008 r. Bronisław Marciniak. W tym okresie stworzono zręby instytucjonalne współpracy - podpisano umowy; odbyły się też pierwsze szkoły letnie, staże naukowe, wymiany naukowe i rozpoczęto realizację „studiów równoległych" dla studentów z Humania w Gnieźnie; otwarto Polskiego Centrum Kulturalno-Oświatowego w Humaniu i zorganizowano pierwsze wspólne konferencje. W Gnieźnie dyrektorem Kolegium Europejskiego Gnieźnieńskiego UAM (dziś IKE UAM) był prof. Aleksander Mikołajczak.

2010-2014 - nowe otwarcie

Rektorem UDPU była prof. Natalia Pobirchenko, rektorem UAM prof. Bronisław Marciniak. Początkowe dwa lata, oznaczające zmiany strukturalne i kadrowe, spowodowały krótkotrwałe ograniczenie współpracy. Kolegium Europejskie otrzymało nowe miejsce w strukturze uniwersytetu i zmieniło nazwę na Instytut Kultury Europejskiej UAM, zmieniła się dyrekcja (prof. Leszek Mrozewicz). W tym czasie naukę ukończyli magistranci z Humania studiujący na specjalności Bałkanistyka. Na kierunku Komunikacja europejska prowadzonym już nie przez Wydział Filologii Polskiej i Klasycznej UAM, ale przez Instytut Kultury Europejskiej UAM w 2013 roku rozpoczynają studia magisterskie nowi studenci. W skali ogólnouniwersyteckiej zapoczątkowano też program Erasmus Mundus, w którym brał udział UDPU. Pod koniec tego okresu współpraca była efektywniejsza, zwłaszcza w zakresie dydaktycznym.

2015 r. do 2020 - rozwój współpracy

Rektorem UDPU został Ołeksander Bezludny, rektorem UAM prof. Andrzej Lesicki. IKE UAM nabyło prawa jednostki podstawowej. W IKE UAM studiowało 
kilkanaście osób z UDPU (wykaz statystyk dotyczących liczby studentów przyjmowanych w konkretnym roku akademickim poniżej). Kontynuowany jest program „Erasmus” oraz wspólne działania wydawnicze.

\section{DYDAKTYKA}

Rozwój współpracy akademickiej wiązał się także z liczną grupą studentów zainteresowanych nauką w IKE UAM. Uniwersytet w Humaniu prowadzi od kilkunastu lat zajęcia z języka polskiego, w związku z tym kadra i studenci zainteresowani byli wyjazdami, które pozwoliłyby na pogłębienie znajomości języka.

W ramach współpracy międzyuczelnianej studenci z Humania uczestniczą w programach naukowych tzw. studiów paralelnych. Program ten ewoluował. W okresie funkcjonowania Kolegium Europejskiego (do 2010 roku) działał program skierowany do studentów z Humania, chcących studiować na funkcjonującej wówczas specjalności bałkanistyka. Prawo rozpoczęcia nauki w Kolegium mieli studenci UDPU, którzy po ukończeniu pierwszego roku studiów na własnym wydziale uzyskali średnią ocen minimum 4,0 (w 5-stopniowej skali). Egzaminy wstępne przeprowadzane były w dwóch etapach - ocena ankiety przesłanej przez kandydata oraz rozmowa kwalifikacyjna na tematy zaproponowane przez studentów ${ }^{27}$.

W ramach trójstronnego porozumienia pomiędzy Państwowym Uniwersytetem Pedagogicznym im. Pawła Tyczyny, Uniwersytetem im. Adama Mickiewicza w Poznaniu oraz Uniwersytetem Paisii Hilandersky w Płowdiwie (Bułgaria) zrealizowano projekt „Trzy dyplomy kluczem do mobilności zawodowej” (2006-2010). Wzięło w nim udział 14 studentów UDPU z czterech wydziałów: filologii obcej, filologii ukraińskiej, przyrodniczo-geograficznego i fizyczno-matematycznego. Efektem projektu była możliwość uzyskania tytułu magistra w zakresie specjalności Komunikacja europejska. W 2010 r. 14 studentów ukończyło studia magisterskie w Kolegium Europejskim im. Jana Pawła II w Gnieźnie (IKE UAM) na kierunku Komunikacja europejska, specjalność Bałkanistyka.

Od 2013 roku w ramach ustaleń pomiędzy UDPU i IKE w Gnieźnie funkcjonuje podobny program, nazywany roboczo „studiami równoległymi”, w ramach którego student studiuje równocześnie na obu uczelniach - kierunek wybrany w Humaniu i Komunikację europejską lub Projektowanie kultury w IKE UAM. Dotychczas skorzystało z tej możliwości około 50 studentów.

\footnotetext{
${ }^{27}$ Pol's'kij kul'turno-osvitnìj centr 2021.
} 
Studenci z Uniwersytetu w Humaniu studiujący równolegle w IKE UAM i na Uniwersytecie Pedagogicznym w Humaniu w ramach współpracy z Uniwersytetem Pedagogicznym w Humaniu, przyjęci na studia w danym roku akademickim:

2008-2011 w sumie 14 studentów,

2013/2014 - 2 studentów,

2014/2015 - 9 studentów,

2016/2017 - 9 studentów,

2017/2018 - 15 studentów,

2018/2019 - 7 studentów,

2019/2020 - 6 studentów,

2020/2021 - 4 studentów.

W 2016 roku IKE UAM zorganizowało konkurs „Europa małych Ojczyzn” w edycji ukraińskiej (była też mołdawska) skierowany do młodzieży starszych klas szkoły średniej. Wśród nagrodzonych była uczennica z Humania. Została ona w 2016/2017 studentką kierunku Komunikacja europejska, ukończyła studia licencjackie w IKE UAM i kontynuuje naukę na studiach magisterskich.

O przenikaniu się współpracy miasta Gniezna, powiatu gnieźnieńskiego i uczelni z Humania oraz IKE UAM świadczy ufundowanie w latach 2014-2020 kilkunastu stypendiów dla studentów z Humania. Studenci od 2014 roku otrzymują także stypendia im. dra Kulczyka. W sumie beneficjantami trzech programów stypendialnych, w których przekazywaniu pośredniczy IKE UAM, było około trzydziestu studentów z Humania.

\section{NAJWAŻNIEJSZE DZIAŁANIA W RAMACH WSPÓŁPRACY PUBLIKACJE, KONFERENCJE, STAŻE, WIZYTY (CHRONOLOGICZNIE)}

- „Ukraińsko-polski dialog naukowy w Humaniu” - publikacje pokonferencyjne $(2008,2010,2016)$;

- staże doktorantów i pracowników naukowych w Kolegium Europejskim i w IKE UAM: w 2007 r. - 3 osoby, w 2008 roku - 8 osób, w 2009 roku 3 osoby;

- publikacja w czasopiśmie związanym z Uniwersytetem im. P. Tyczyny w Humaniu (Jędraszczyk 2010b);

- udział 4 pracowników naukowych z Humania w konferencji „Ukraina Polska -Unia Europejska. Polityczny, gospodarczy i społeczno-kulturalny wymiar współpracy", 19-20 maja 2011 r. Publikacje: I. Krywoszeji, O. Zabołotnej, L. Wojtowej, L. Zagorujko w monografii pokonferencyjnej (Ukraina - Polska - Unia Europejska 2012); 
- czerwiec 2013 r. wizyta studyjna dr Jędraszczyk na Uniwersytecie Pedagogicznym w Humaniu, prezentacja oferty edukacyjnej IKE UAM, robocze spotkanie dotyczące organizacji programu „studiów równoległych”;

- udział 6 pracowników z Uniwersytetu Pedagogicznego w Humaniu w międzynarodowej konferencji organizowanej przez IKE w Gnieźnie „Jawne i ukryte sensy komunikacji kulturowej" w 2013 r., publikacja dr Ludmiły Zagorujko „Intercultural Dialogue: Language Aspect” z Uniwersytetu im. Pawła Tyczyny w Humaniu w monografii „Explicit and Implicit Meanings" z roku 2015;

- Wykłady gościnne doc. Ihora Krywoszeji dotyczące zakonu bazylianów w Humaniu oraz powstania styczniowego (2013 i 2014). Wystawa i wykład doc. dr Ihora Krywoszeji - Powstanie styczniowe na Humańszczyznie listopad 2013;

- 20-21.04.2016 - wizyta studyjna na UDPU dyrektora IKE UAM prof. Leszka Mrozewicza i dr Katarzyny Jędraszczyk. Spotkania z władzami uczelni, studentami oraz w Polskim Centrum Kulturalno-Oświatowego przy uniwersytecie w Humaniu;

- udział prof. Łukomskiego i dr Wasilkiewicza z IKE UAM w konferencji w Humaniu dotyczącej stosunków polsko-ukraińskich (maj 2016);

- udział w uroczystościach Dnia Nauki na Ukrainie i rozpoczęciu roku akademickiego Katarzyny Jędraszczyk (2018) i Igora Ksenicza (2019);

- publikacja z udziałem rektora Uniwersytetu Pedagogicznego im. P. Tyczyny w Humaniu - prof. Ołeksandra Bezludnego (Jędraszczyk, Krasiwski, Bezludny 2016);

- konferencja międzynarodowa z udziałem dr Katarzyny Jędraszczyk (IKE UAM) -„Ukraïna ì Pol’ŝa: minule, sučasne, majbutnê”, 22-23 maja 2018, Ministerstwo Oświaty Ukrainy, Humański Uniwersytet Pedagogiczny im. P. Tyczyny w Humaniu, Ambasada RP na Ukrainie, referat: „Vìd strategičnogo partnerstva do pragmatizmu: pol's'ko-ukraïns'kì stosunki u 2005-2017” wygłoszony po ukraińsku na sesji planarnej, wizyta studyjna, spotkanie ze studentami w Humaniu;

- publikacja w czasopiśmie związanym z UDPU (Jędraszczyk 2018);

- Konferencja międzynarodowa „Innowacijiw suczasnij oswiti: ukrajins'kj ta switowyj konteksty", 18-19.04.2019 r. z udziałem prof. Grażyny Gajewskiej (IKE UAM) - referat „Posthumanim, nowy materializm, antropologia rzeczy - nowe perspektywy badawcze i edukacyjne” i dr Katarzynay Jędraszczyk (IKE UAM) „Implementacja polityki historycznej państwa poprzez system edukacji szkolnej - perspektywa polskiego i ukraińskiego systemu kształcenia”. 


\section{WNIOSKI}

O skuteczności i trwałości umowy między uniwersytetami, od której podpisania minęło 15 lat, zdecydował zapewne fakt, że była ona efektem oddolnych inicjatyw, działania były wielokierunkowe, a zaangażowane w nie były przede wszystkim mniejsze jednostki uniwersyteckie (instytuty, wydziały). Nie bez znaczenia była też sprzyjająca atmosfera ze strony władz obu uniwersytetów, wspieranie inicjatyw przez samorządy Gniezna i Humania, włączanie się środowiska akademickiego do przedsięwzięć realizowanych przez miasta i odwrotnie, osobiste zaangażowanie koordynatorów i poszczególnych pracowników naukowych. Połączenie tych uwarunkowań stwarza duże szanse skuteczności realizacji bilateralnych umów uniwersyteckich.

\section{FROM CITY COOPERATION TO ACADEMIC COOPERATION - THE EXAMPLE OF THE PAVLO TYCHYNA UMAN STATE UNIVERSITY AND THE ADAM MICKIEWICZ UNIVERSITY IN POZNAŃ (AMU INSTITUTE OF EUROPEAN CULTURE)}

\section{Summary}

Many cities and universities started cultural and academic cooperation in the 1990s and 2000s. Practice has shown that not always relations, especially those with local governments, were effective enough and resistant to political changes. An example of good practice in this respect is the partnership of the towns of Uman and Gniezno. This served as a basis to establish the academic relations between the of Pavlo Tychyna Uman State Pedagogical University and the Adam Mickiewicz University in Poznań, especially the AMU Institute of European Culture in Gniezno (formerly the European College, Adam Mickiewicz University). The description of the scientific, cultural and teaching activities of both centers suggests a model of cooperation built on the basis of regular grassroots activity.

The effectiveness and durability of the agreement between the universities is determined by a favorable atmosphere on the part of university authorities, support for the initiative shown by the local governments, cooperation initiatives at the level of faculties and institutes, personal commitment of the coordinators and individual researchers. The combination of these factors creates great opportunities for an effective implementation of bilateral university agreements.

\section{Bibliografia}

\section{Akty prawne, dokumenty}

Porozumienie o współpracy między Ministrem Edukacji Narodowej Rzeczypospolitej Polskiej a Ministerstwem Oświaty i Nauki Ukrainy, sporządzone w Górowie Iławeckim dnia 2 lipca 2001 r. M.P. 2002, nr 6, poz. 127.

Umowa między Rządem Rzeczypospolitej Polskiej a Rządem Ukrainy o współpracy w dziedzinie kultury, nauki i oświaty, sporządzona w Kijowie dnia 20 maja 1997 r., Dz.U. 2000, nr 3, poz. 29. 
Ugoda pro stvorennâ kul'turno-osvitn'ogo centru z oseredkom v Umans'komu deržavnomu pedagogì̌nomu unìversitetì ìmenì Pavla Tičini.

Ugoda pro stvorennâ Pol's'kogokul'turno-osvitn'ogo centru z oseredkom v Umans'komu deržavnomu pedagogičnomu unìversitetì ìmenì Pavla Tičini. V ramkah ugodi miž Umans'kim deržavnim pedagogìčnim unìversitetom ìmenì Pavla Tičini ì Unìversitetom ìmenì Adama Mìckeviča v m. Poznan' pìdpisanoï 3.10.2005 roku v m. Umanì 21.11.2007.

\section{Publikacje}

Brì N., Zabolotna O., 2011 traven', Mǐ̌kul'turnìporìvnânnâ pìd čas litn’ö praktiki? Tak! Âkŝo vi učasnik mì̌narodnih program, Pedagogičnì vìstì.

Džagunova O.İ. 2017, Spivvrobìtnictvo Umans'kogo deržavnogo pedagogičnogo unìversitetu ìmenì Pavla Tičini z naukovo-osvìtnìmi ustanovami Respubliki Pol’ŝa: ìstoričnij naris, [w:] Historia III. Polsko-ukraińskie spotkania z Klio, Częstochowa.

Explicit and Implicit Meanings of Cultural Communication/Âvnye i skrytye smysly kul'turnoj kommunikacii, editor Katarzyna Jędraszczyk, Wydawnictwo Naukowe Contact/ABC, Gniezno 2015.

Jędraszczyk K. 2010, Strategiczne partnerstwo ukraińsko-polskie. Polska w polityce niepodległej Ukrainy, Poznań.

Jędraszczyk K. 2010b, Ukraïns'ko-pol's'ka superečka navkolo vìdbudovikladoviŝa Orlât u L'vovì, [w:] Ukraïrsko-pol's'kijna naukovij dìalog v Umanì, 2: Formuvannâ sučasnogo arhìtekturnogo seredoviŝa ìstoričnih mìst - na osnovì reabìlìtacii ìstoriko-mìstobudìnnoï spadŝini, Uman'-GneznoLan'cut-Poznan' 2010, s. 61-68.

Jędraszczyk K. 2018, Vìd strategìčnogo partnerstva do pragmatizmu: pol's'ko-ukraïns'kì stosunki u 2005-2017 rr., Uman'ska starovina 5, s. 45-55.

Jędraszczyk K., Krasiwski O., Bezludny O. et al. 2016, Społeczeństwo i kultura Ukrainy. Ćwierćwiecze przemian 1991-2016, Gniezno.

Kirej R. 2016, Reforma. Akademična mobil'nìst'priskorûê ìntegracîu [online]. Urâdovij kur`êr, 8 červnâ [dostęp: 2011-03-22]. Dostępny w Internecie: <ukurier.gov.ua/uk/articles/akademichna-mobilnist-priskoryuye-integraciyu/>.

Krivošeâ İ. 2011, Miždisciplìnarnì ìndivìdual'nì gumanìtarnì studï (MİGUS) v Umans'komu deržavnomu unìversitetì ìmenì Pavla Tičini, [w:] Rozvitok osvìtnìh sistem u global'nomu vimìrì: tendenciiì prognozi: Materìalimìžnarodnoï naukovoï konferencji (26-27 travnâ 2011), PP Žovtij, Častina I, Uman'.

Krivošeâ İ. 2012, Partnerstvo Gnêzno - Uman': 10 klûčiv uspihu, [w:] K. Jędraszczyk, O. Krasiwski, W. Sobczak (red.), Ukraina - Polska - Unia Europejska: polityczny, gospodarczy i społeczno-kulturalny wymiar współpracy, Poznań.

Krivošeâ İ., Zabolotna O. 2010, Ruh mìst-pobratimìv v kontekstì pol's'ko-ukraïns'kogo spìvrobìtnictva: partnerstvo Umanì z Lan'cutom ì Gnêznom, Naukovì zapiski [Nacìonal'nogo unìversitetu „Ostroz'ka akademiầ], Seriâ: Polìtičnì nauki, 4.

Krivošeâ İ., Zabolotna O. 2011, P'ât' rokì partnerstva Uman' (Ukraïna) - Gnêzno (Pol’ŝa): spil'na êvropejs'ka perspektiva, Naukovì zapiski Vìnnic'kogo deržavnogo pedagogičnogo unìversitetu İmenì Mihajla Kocûbins'kogo 19, Seriâ: İstoriâ: Zbìrnik naukovih prac', za zag. red. prof. P.S. Grigorčuka, Vìnnicâ.

Krivošeâ İ., Zabolotna O. 2012, Spìvpracâ z Pol'ŝeû âk šlâh ìntegracii v Êvropejs'kij Soûz: Umans’kij deržavnij pedagogičnij unìversitet nanivì pol's'ko-ukraïns'koï spivpracì (2005-2009 rr.), [w:] Polska-Ukraina. Dziedzictwo i współczesność, Słupsk. 
Krivošeâ I., Zabolotna O.A. 2013, Sìm rokìv partnerstva: Umans'kij deržavnij pedagogičnij unìversitet ì Unìversitet ìmenì Adama Mìckeviča v Poznanì, [w:] J. Migdał, A. Piotrowska-Wojaczyk (red.), Cum reverentia, gratia, amnicitia... Księga jubileuszowa dedykowana profesorowi Bogdanowi Walczakowi, Poznań.

Krywoszeja I., Zabolotna O. 2009, Działalność Humańskiego Pedagogicznego Uniwersytetu Pedagogicznego im. Pawła Tyczyny na polu polsko-ukraińskiej współpracy naukowo-edukacyjnej, [w:] Postscriptum polonistyczne, Katowice, s. 267-270.

Miżnarodni zwjazky [online]. Umans'kijderžavnij pedagogičnij unìversitet ìmenì Pavla Tičini [dostęp: 2021-03-22]. Dostępny w Internecie: <https://uman-rada.gov.ua/index.php/nashe-misto/ mizhnarodni-zviazky>.

Muzičenko Û. 2009, Organìzacìjnì zasadi funkcìonuvannâ program akademìčnoï mobìlnostì v ukraïns'kih na prikladì Umans'kogo deržavnogo pedagogičnogo unìversitetu ìmenì Pavla Tičini, Porìvnâl'no pedagogičnì studiï 2.

Nasz Uniwersytet Zbahaczuje Istoryczni Archiwy Pol'szczi 2013 [online]. Umans'kijderžavnij pedagogìčnij unìversitet ìmenì Pavla Tičini [dostęp: 2021-03-22]. Dostępny w Internecie: <https:// udpu.edu.ua/news/nash-universytet-zbahachuye-istorychni-arkhivy-polshchi>.

Pilipenko Ê. 2009, Pol's'ko-ukraïns'kij molodižnij obmìn, Umans'ka zorâ, 2 travnâ.

Pilipenko Ê. 2009, Uman' - Gnêzno: proektispìvpracì, Umans'ka zorâ, 7 listopada.

Pol's'kij kul'turno-osvìtnì centr [online]. Umans'kijderžavnij pedagogičnij unìversitet ìmenì Pavla Tičini [dostęp: 2021-03-22]. Dostępny w Internecie: <http://pkoc.udpu.org.ua/>.

Poznaj nasz Instytut [online]. UAM [dostęp: 2021-03-22]. Dostępny w Internecie: <http://ike.amu. edu.pl/poznaj-nasz-instytut/>.

Stažuvannâ u Pol'ŝ̀ za programoû ERASMUS Plus [online]. Umans'kijderžavnij pedagogičnij universitet ìmenì Pavla Tičini [dostęp: 2021-03-22]. Dostępny w Internecie: <http://pkoc.udpu. org.ua/?p=1668>.

Tocenko Ž. 2012, Spìvpracâ v galuzì kul'turi âkskladova ukraïns'ko-pol's'kih gumanìtarnih vìdnosin, avtoref. dis. kand. ìst. nauk: 26.00.01, Kiïv. nac. un-t kul'turi ì mistec.

Ukraina - Polska - Unia Europejska. Polityczny, gospodarczy i społeczno-kulturalny wymiar współpracy, red. K. Jędraszczyk, O. Krasiwski, W. Sobczak, Poznań-Gniezno 2012.

Zvì z mižnarodnoï diâl'nostì Umans'kogoderžavnogo pedagogičnogo unìversitetu ìmenì Pavla Tičini, opr. O.A. Zabolotna, Uman' 2007. 